\title{
Diversity of trees and structure of forest habitat types in Mt. Tago Range, Mindanao, Philippines
}

\author{
Fulgent P. Coritico ${ }^{1, *}$, Noel E. Lagunday ${ }^{1}$, John Michael M. Galindon ${ }^{2}$, Danilo N. Tandang ${ }^{2}$ and \\ Victor B. Amoroso 1
}

\begin{abstract}
Mt. Tago Range in Bukidnon has been subjected to deforestation and forest fragmentation due to logging $c a$. 35-40 years ago or as direct result of land conversion for agriculture, human settlements and wildlife product harvesting. It is currently not a protected area. This study aimed to provide data on the tree species diversity, structure, composition, conservation status and threats of the forest habitats in the site. Tree survey in the range was conducted in 2018-2019 using thirty-nine $20 \times 20 \mathrm{~m}$ sampling plots and six one-kilometer transect lines. A total of 1,032 tree individuals from 54 families, 85 genera and 121 species were documented. The site is composed of four tropical forest habitat types namely: lower montane rainforest, upper montane rainforest, mossy-pygmy and forest over ultramafic rocks. These forest habitats also differed in species composition, elevation, substrate, dominance and structure in terms of height and diameter at breast height. The highest diversity index was observed in the mid-elevation and decreasing toward the peak. The diversity pattern herein is attributed to elevation, forest degradation due to anthropogenic activities and nature of habitat. The most abundant families were the Myrtaceae (23\%), Podocarpaceae (12.8\%) and Fagaceae (12.6\%). At the family level the most dominant taxa included the Moraceae (8.7\%), Rubiaceae (6.5\%) and Myrtaceae (5.8\%). Highest importance value index (IVI) in all forest types fell within the range of IVI's for tropical forests. Assessment of conservation and ecological status revealed that 11 species (8\%) are threatened, 28 (22\%) Least Concern (LC) and 16 (12\%) are Philippine endemics. Threats to tree diversity in Mt. Tago Range included land conversion for agriculture and settlement, illegal logging and lack of legislative protection. The implementation of conservation strategies by stakeholders is recommended to protect the tree species communities and population across the forest habitat types in the site.
\end{abstract}

Keywords: biodiversity, flora, Shannon-Weiner Index, Importance Value Index, non-Protected Area

\section{Introduction}

The Philippines is considered one of the world's biodiversity hotspots (Myers et al., 2000). Its various primary forests are home to 10,158 species of flora (Pelser et al., 2011 onwards) but threatened by the plummeting natural forest cover (Suarez \& Sajise, 2010; Apan et al., 2017).

\footnotetext{
${ }^{1}$ Center for Biodiversity Research and Extension in Mindanao (CEBREM), and Department of Biology, Central Mindanao University, Musuan, Bukidnon, Philippines

${ }^{2}$ Philippine National Herbarium (PNH), Botany Division, National Museum of the Philippines, P. Burgos St., Manila, Philippines
}

*Corresponding email: cfulgent@gmail.com

Date Submitted: 06 May 2020

Date Accepted: 30 September 2020
The deforestation rate in the Philippines from 1993-2000 is estimated at 100,000 ha annually (Cruz \& Zosa-Feranil, 1998) and 50,000 ha from 2003-2010 (Sibucao et al., 2014). Prior to Spanish colonization of the Philippines in the $16^{\text {th }}$ century, $c a$. $90 \%$ of land area was covered with lush forests which was reduced to $70 \%$ due to logging during the three centuries of Spanish colonization. In 1950 after half a century of American and Japanese occupation, forest cover plummeted to $50 \%$ (Bankoff, 2007). Recent published estimates of the remaining forest cover is as low as $17-18 \%$ of the total land area (Moya \& Malayang, 2004; Posa \& Sodhi, 2006; Briones, 2007).

A few botanical expeditions in Mt. Tago Range have been recently conducted by Gronemeyer et al. (2014), Coritico and Fleischmann (2016) and Coritico et al. (2017) which led to the discovery of two new species of pitcher plants and new records of sundews and tree ferns. 
Although Mt. Tago Range is considered as a priority conservation area under the Philippine Key Biodiversity Areas (KBA)- based conservation approach (Ambal et al., 2012), the area remains unprotected and is not covered by any legislative measures. As a result, the mountain range was subjected to various anthropogenic activities such as massive deforestation ca. 30-45 years ago, land conversion for agriculture, human encroachment, and poaching. The current study aims to provide data on the tree species diversity, structure, composition, conservation status and threats to the forest habitats in the site as critical baseline information for establishing long-term monitoring and assessment programs.

\section{Materials and Methods}

\section{Study area and identification of forest habitat types}

The study was conducted at Mt. Tago Range in Bukidnon, Mindanao, Philippines (Fig. 1). It has a total land area of 35,317 ha supporting the Tagoloan River watershed, a single river basin that covers an area of 167,793 ha in 10 municipalities along Bukidnon province, Cagayan de Oro City and Tagoloan, Misamis Oriental (Bukidnon Watershed Protection and Development Council, 2012) and the upper Pulangi River. In this study, it is estimated that the entire range has lost $c a$. 30$45 \%$ of its forest cover due to illegal logging and land conversion for agriculture and human settlement. Sphagnum bog was observed at about 1,877 masl which is the habitat of a unique carnivorous plants Drosera rotundifolia L., a new record for the Philippines (Coritico \& Fleischmann, 2016) and two recently described pitcher plants (Gronemeyer et al., 2014). In this study, the classification of forest types was based on Fernando et al. (2008).

\section{Sampling, processing, and identification}

Botanical fieldwork was conducted between 2018 and 2019 using thirty-nine $20 \times 20 \mathrm{~m}\left(400 \mathrm{~m}^{2}\right)$ sampling plots with a distance of at least $20 \mathrm{~m}$ between plots situated along different forest habitat types in Mt. Tago Range (Fig. 1). A total of 11 plots were established and inventoried in the lower montane forest, upper montane forest and mossy-pygmy forest. However, only 6 plots were done in the forest over ultramafic rocks due to limited access and time. A total of six 1-kilometer transect lines were established and inventoried at least twice listing trees and associated species i.e., ferns and understory plants. The diameter at breast height $(\mathrm{DBH})$, tree height and basal area (BA) of trees with at least $10 \mathrm{~cm}$ DBH were computed. The measurement of DBH and tree height was done using a diameter tape and laser rangefinder, respectively. Trees were categorized into different size classes, namely: 10-19 cm,

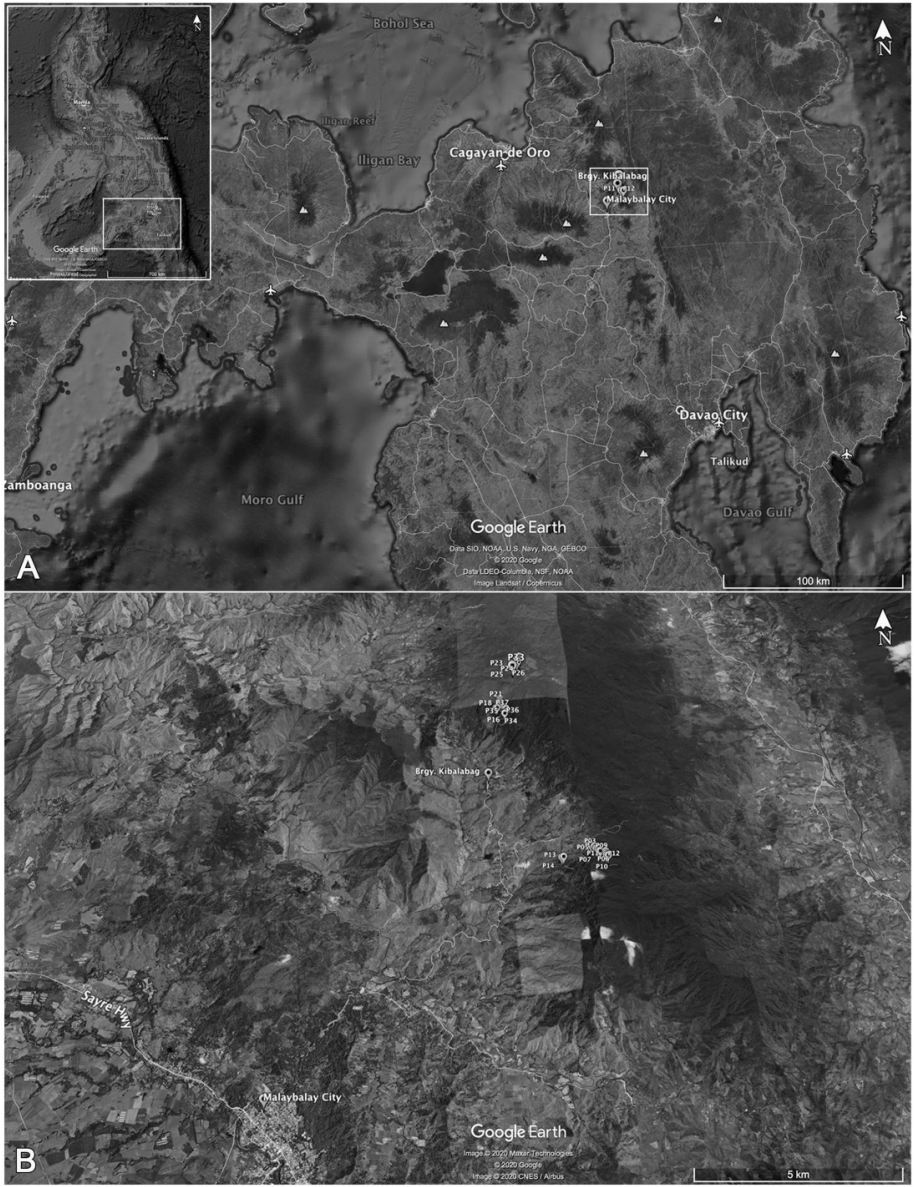

Figure 1. Location of the study areas and plots in Mt. Tago Range. A) location of Mt. Tago Range in Mindanao Island, Philippines; B) study areas in Mt. Tago Range: Mt. Limbawon (upper right) and Mt. Manugawi (lower right)

20-29 cm, 30-39 cm and $\geq 40 \mathrm{~cm}$ (Lulekal et al., 2008), while height in each forest habitat type was categorized into lower canopy (1-15 m), upper canopy (16-30 m) and emergent (31 m and up).

Representative herbarium specimens were collected, pressed and dried using customized mechanical herbarium dryers. Specimens were deposited at the Central Mindanao University Herbarium (CMUH) and National Museum of the Philippines (PNH).

Classification and identification were employed with the use of online databases (i.e. Global Plants on JSTOR, Co's Digital Flora of the Philippines) and published journal articles. Conservation status of the species in Mt. Tago was determined based on DENR Administrative Order (DAO) 2017-11 and IUCN Red List (2020).

\section{Data treatment and analysis}

The biodiversity index values were calculated following Simpson (1949), Shannon and Wiener (1949) and Magurran 
(2004). The Shannon-Wiener index $\left(H^{\prime}\right)$ was applied as a measure of both species abundance and richness to quantify diversity of the tree species while Simpson's index of diversity gave the probability that any two individuals drawn at random from an infinitely large community belonging to the same species. Calculation for frequency, relative frequency, density, relative density, dominance, relative dominance and Importance Value Index (IVI) was derived from Nguyen et al. (2014). Statistical analysis softwares i.e., Minitab 19 and BioDiversity Professional version 2 were used in the analysis of variance and species accumulation curve.

The following formulae were used:

Shannon-Wiener Index $\left(H^{\prime}\right)=-\quad \sum_{i=1}^{s} P i \ln P i$

where $s=$ the number of species and $P i=$ proportion of individuals or abundance of the $i^{\text {th }}$ species expressed as a proportion of total cover; and $\ln =\log$ base $n$.

Density $=\frac{\text { Number of individuals of a species }}{\text { Total area sampled }}$
Frequency $=\frac{\begin{array}{c}\text { Total no. of quadrats in which the } \\ \text { species occurred }\end{array}}{\text { Total no. of quadrats sampled }}$
Relative Frequency $(\mathrm{RF})=\frac{\text { Frequency of a species }}{\begin{array}{c}\text { Total frequency of } \\ \text { all species }\end{array}} \times 100$

Total basal area of a

Relative Dominance $($ Rdom $)=\frac{\text { species }}{\text { Total basal area of }} \times 100$ all species

Relative Density $(\mathrm{RD})=\frac{\text { Density of a species }}{\text { Total density of all species }} \times 100$

Basal Area $\left(\mathrm{m}^{2}\right)=\mathrm{Pi} * \mathrm{DBH}(\mathrm{cm})^{2} / 40000$

and

Species Importance Value Index (IVI) $=\mathrm{RD}+\mathrm{RF}+\mathrm{Rdom}$.

\section{Results and Discussion}

Tree species richness and composition across forest habitat types

A total of 1,032 individual trees from 54 families, 85 genera and 121 species were documented. The results were comparable with the tree species in the disturbed habitats of Mt.
Apo which has 136 species (Zapanta et al., 2019) and Mt. Hamiguitan expansion sites with 124 species of trees and shrubs (Amoroso et al., 2018). Species richness in Mt. Tago is much higher compared to Mt. Malindang $(\mathrm{n}=86)$ (Arances et al., 2004), Southern Mindanao ( $\mathrm{n}=117)$ (Gregorio et al., 2009), Mount Lantoy (KBA) in Cebu ( $\mathrm{n}=112)$ (Lillo et al., 2019) and it is lower compared to Mt. Calavite Wildlife Sanctuary in Mindoro with 181 species (Malabrigo et al., 2020).

The most abundant families were the Myrtaceae (23\%), Podocarpaceae (12.8\%) and Fagaceae (12.6\%). At the family level the most represented taxa included the Moraceae (12 species; 10\%); Myrtaceae ( 8 species; 6\%); Lauraceae (7 species; 6\%); Rubiaceae (6 species; 5\%); Euphorbiaceae, Fagaceae and Podocarpaceae (5 species each; 4\%); Araliaceae (4 species; 3\%); Actinidiaceae, Burseraceae, Dipterocarpaceae, Meliaceae, Melastomataceae, Primulaceae, Rutaceae, Sapotaceae and Urticaceae with 3 species each (2\%). The remaining 38 families were represented by fewer than 3 species each (Table 1). Moraceae, Lauraceae, Euphorbiaceae and Myrtaceae were also observed to be the most abundant taxa in the disturbed habitats of Mt. Apo Natural Park (Zapanta et al., 2019); rubber plantation in Makilala, Cotabato (Gregorio et al., 2009) and in Samar, Philippines (Madulid, 2000). Ficus L. is reported herein as the most abundant genus, observed mostly in the disturbed patches. This finding is similar to the findings of Polinar \& Muuss (2010) in the secondary forest of Mount Pangasugan, Leyte; Zapanta et al. (2019), Gregorio et al. (2009) and Madulid (2000). The abundance of this genus is attributed to different species being able to thrive in a wide range of altitudinal gradient and by being dispersed by many birds and bats (Gregorio et al., 2009).

\section{Biodiversity indices and species richness in the forest habitat types \\ Species diversity mean values using Shannon-Wiener (Fig.} 2) and Simpson's diversity index (Fig. 3) were highest in the upper montane followed by the lower montane, forest over ultramafic rocks and lowest in the mossy-pygmy forest. One way analysis of variance (ANOVA) showed that the mossypygmy forest has a significantly low $(P<.001)$ diversity values compared to the tropical lower and upper montane and forest over ultramafic rocks.

Low mean species diversity $\left(H^{\prime}=1.2\right.$ and Simpson's Diversity index $=0.7$ ) in the mossy-pygmy forest was attributed to poor species richness due to the unique ultramafic nature and peat bog habitat dominated by Dacrydium beccarii Parl. (Podocarpaceae) with 30-100\% dominance and Leptospermum amboinense Blume (Myrtaceae) (46-60\%) in the plots (Table 2.). The findings were consistent with the findings of Causaren 
Table 1. Tree species abundance per family across forest types.

\begin{tabular}{|c|c|c|c|c|c|c|c|c|}
\hline Taxa & $\begin{array}{c}\text { No. of } \\
\text { Genera }\end{array}$ & $\begin{array}{c}\text { No. of } \\
\text { Species }\end{array}$ & Taxa & $\begin{array}{c}\text { No. of } \\
\text { Genera }\end{array}$ & $\begin{array}{c}\text { No. of } \\
\text { Species }\end{array}$ & Taxa & $\begin{array}{c}\text { No. of } \\
\text { Genera }\end{array}$ & $\begin{array}{c}\text { No. of } \\
\text { Species }\end{array}$ \\
\hline Aceraceae & 1 & 1 & Ericaceae & 1 & 1 & Pentaphylacaceae & 1 & 1 \\
\hline Actinidiaceae & 1 & 3 & Escalloniaceae & 1 & 1 & Phyllanthaceae & 2 & 2 \\
\hline Anacardiaceae & 1 & 1 & Euphorbiaceae & 2 & 5 & Pittosporaceae & 1 & 1 \\
\hline Apocynaceae & 2 & 2 & Fagaceae & 2 & 5 & Podocarpaceae & 5 & 5 \\
\hline Araucariaceae & 1 & 1 & Gentianaceae & 1 & 2 & Primulaceae & 2 & 3 \\
\hline Bignoniaceae & 1 & 1 & Gnetaceae & 1 & 1 & Proteaceae & 1 & 1 \\
\hline Burseraceae & 2 & 3 & Grewiaceae & 1 & 1 & Rubiaceae & 6 & 6 \\
\hline Calophyllaceae & 1 & 2 & Juglandaceae & 1 & 1 & Rutaceae & 3 & 3 \\
\hline Cannabaceae & 1 & 1 & Lamiaceae & 1 & 1 & Sabiaceae & 1 & 1 \\
\hline Casuarinaceae & 1 & 1 & Lauraceae & 4 & 7 & Sapindaceae & 2 & 2 \\
\hline Celastraceae & 1 & 1 & Magnoliaceae & 1 & 1 & Sapotaceae & 2 & 3 \\
\hline Chloranthaceae & 1 & 1 & Melastomataceae & 3 & 3 & Staphyleaceae & 1 & 1 \\
\hline Clethraceae & 1 & 1 & Meliaceae & 2 & 3 & Stemonuraceae & 1 & 1 \\
\hline Clusiaceae & 1 & 1 & Monimiaceae & 1 & 1 & Sterculiaceae & 1 & 1 \\
\hline Combretaceae & 1 & 1 & Moraceae & 2 & 12 & Symplocaceae & 1 & 1 \\
\hline Cunoniaceae & 1 & 1 & Myristicaceae & 2 & 2 & Theaceae & 2 & 2 \\
\hline Dipterocarpaceae & 1 & 3 & Myrtaceae & 3 & 8 & Urticaceae & 2 & 3 \\
\hline Elaeocarpaceae & 1 & 2 & Oleaceae & 1 & 1 & Winteraceae & 1 & 1 \\
\hline
\end{tabular}

Total number of families: 54

Total number of genera : 85

Total number of species : 121

et al. (2017) in the forest fragments in Cavite, Luzon, where sites dominated by few species result in lower species diversity. However, lower species diversity in lower elevations is attributed to logging $c a$. 35-40 years ago, land conversion for agriculture and human settlements and continued wildlife product harvesting.

The highest diversity index was observed in the midelevation and decreasing toward the peak as observed in the study and is consistent with findings in Mt. Hamiguitan and Mt. Kitanglad (Amoroso 2006; Amoroso et al., 2009; Amoroso et al., 2011; Amoroso et al., 2012). The diversity pattern herein is attributed to elevation, forest degradation due to anthropogenic activities and nature of habitat which is comparative to the findings of Malabrigo et al. (2020).

Despite the sampling effort the species accumulation curve (Fig. 4) suggested that more individuals and species will be encountered and recorded with more sampling in the lower montane, upper montane and forest over ultramafic rocks. It also suggested that less sampling effort is needed in the mossy pygmy forest.

\section{Forest formations}

The site was composed of four tropical forest formations (Fernando et al., 2008) namely: tropical lower montane rainforest (1200-1500 masl), tropical upper montane rainforest (1500-1800 masl), mossy-pygmy forest (1800-1900 masl) and forest over ultramafic rocks (1500-1700 masl) with average basal area of $1.7 \mathrm{~m}^{2} /$ ha.

\section{Tropical lower montane rainforest}

The lower montane forest at $c a$. 1200-1500 masl was characterized by clay and loam substrate (Table 2), emergent trees ( $\geq 31 \mathrm{~m}$ tall) $(92 \%), 10-19 \mathrm{~cm} \mathrm{DBH} \mathrm{(54 \% )} \mathrm{and} 1.5 \mathrm{~m}^{2} /$ ha average basal area (BA) (Table 3). Buttressed trees were rare and woody vines were usually absent. Dominant species were Lithocarpus philippinensis (A.DC.) Rehder (Philippine Oak) 


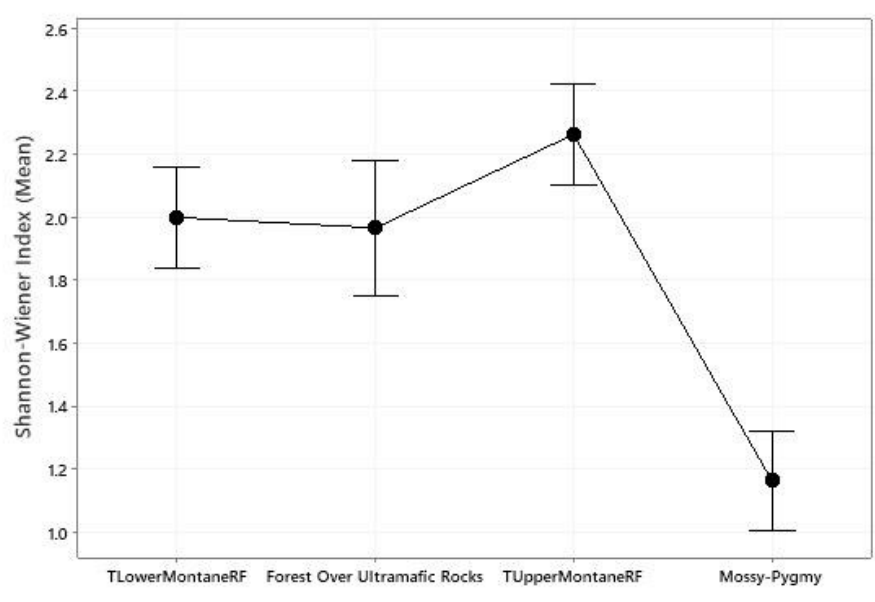

Figure 2. Shannon-Wiener index for the different forest habitat types in Mt. Tago Range.

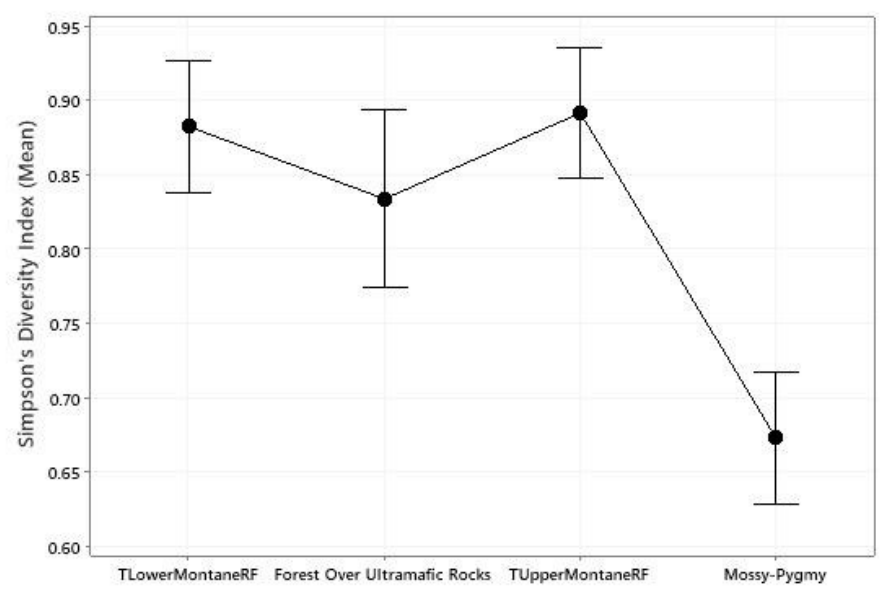

Figure 3. Simpson's diversity index for the different forest habitat types in Mt. Tago Range.

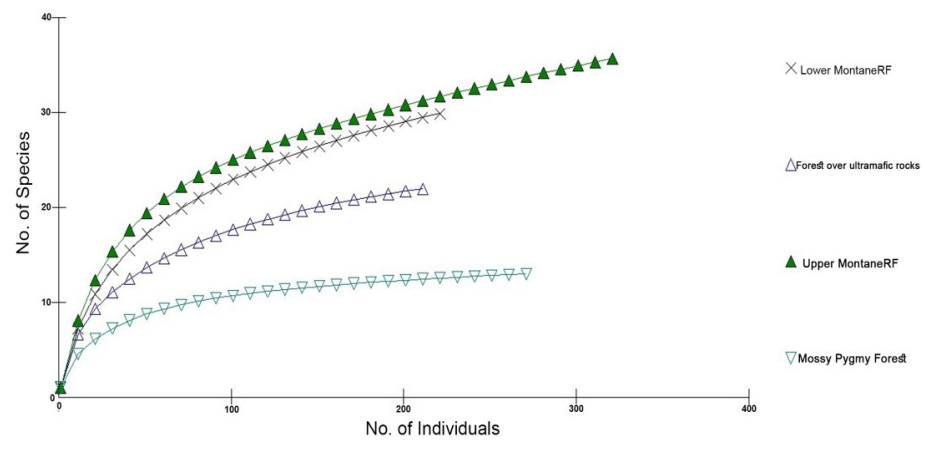

Figure 4. Species accumulation curves for the four forest habitat types in Mt. Tago Range.
(Fagaceae) with mean dominance (Table 2) of 36.5, importance value index (Table 4) (IVI) of 47 and Syzygium sp. 1 (Myrtaceae), 36.5 mean dominance and 24 IVI suggesting an Oak-Syzygium assemblage almost similar to Ashton's (2003) oak-laurel assemblage. Other dominant tree taxa included Lithocarpus sp. 1, Acronychia sp. and Palaquium sp., tree with highest DBH recorded, Agathis philippinensis Warb. (150 cm). Emergent trees were Shorea polysperma Merr., Syzygium sp. and A. philippinensis. The dominant ferns and lycophytes in this vegetation included the Mindanao endemic scaly tree fern, Alsophila rufopannosa R.M. Tryon, Alsophila commutata Mett., Alsophila lurida (Blume) Hook., Blechnum vulcanicum Kuhn, Davalia repens (L.f.) Kuhn, Hymenophyllum polyanthos Sw., Lycopodiella cernua (L.) Pic. Serm., Plagiogyria egenolfioides (Baker) Copel., Selliguea taeniata (Sw.) Parris, Selaginella involvens Sw. Spring and Tapeinidium pinnatum (Cav.) C. Chr. Other understory plants include site endemic pitcher plants, Nepenthes pantaronensis Gieray et al., N. surigaoensis Elmer, Areca costulata Becc., Calamus microcarpus Becc., Coelogyne candoonensis Ames, Dendrochilum apoense T. Hashim., Freycinetia cumingiana Gaudich., Heterospathe philippinensis (Becc.) Becc., Mackinlaya celebica (Harms) Philipson, Osmoxylon simplicifolium (Elmer) Philipson, Pandanus sp., Pinanga philippinensis Becc. and Smilax reticulata Elmer.

\section{Tropical upper montane rainforest}

This forest type in the Philippines is commonly called the mossy forest, a name used by Whitford (1911) in reference to the abundance of mosses that cover the trunks and branches of trees. The mossy surroundings and gnarled branch of trees are characteristics of the forest type. Situated at $c a$. 1500-1800 masl is an upper montane characterized by clay and loam substrate, upper canopy (16-30 m tall) (58\%), 10-19 cm DBH (37\%) and $2.5 \mathrm{~m}^{2} / \mathrm{ha}$ average BA. Dominant species were Lithocarpus philippinensis, 34.5 mean dominance, 42.4 IVI and Syzygium sp. (Myrtaceae), 33 mean dominance and 34.4 IVI. Other dominant tree taxa include Lithocarpus sp. 1, Syzygium sp. 4, Syzygium sp. 3 and Agathis philippinensis, tree with highest DBH recorded, Zanthoxylum integrifolium (Merr.) Merr, $(82 \mathrm{~cm})$. Emergent trees were A. philippinensis, Palaquium sp., L. philippinensis and Podocarpus rumphii Blume. The dominant ferns and lycophytes in this vegetation includes Alsophila commutata, A. rufopannosa, Davalia. repens, Dryopteris nodosa (C. Presl) Li Bing, Elaphoglossum callifolium (Blume) T. Moore, E. blumeanum (Fée) J. Sm., Hymenophyllum spp., Lindsaea pulchella (J.Sm.) Mett. ex Kuhn and Plagiogyria egenolfioides. The other understorey plants include the site endemic pitcher plant, Nepenthes pulchra Gronem., S.McPherson, Coritico, Micheler, Marwinski \& V.B.Amoroso., Freycinetia cumingiana, 
Table 2. Dominant tree taxa across forest habitat types.

\begin{tabular}{|c|c|c|c|c|c|}
\hline Forest habitat types & Plots & $\begin{array}{c}\text { Elevation } \\
\text { (masl) }\end{array}$ & Substrate & Dominant Species & $\begin{array}{c}\text { Dominance } \\
(\%)\end{array}$ \\
\hline \multirow{11}{*}{ TLowerMontaneRF } & $\mathrm{P} 01$ & 1262 & Clay/Loam & Shorea polysperma (Blanco) Merr. & 51 \\
\hline & P02 & 1308 & Clay/Loam & Lithocarpus philippinensis (A.DC.) Rehder & 23 \\
\hline & $\mathrm{P} 03$ & 1333 & Clay/Loam & Lithocarpus philippinensis (A.DC.) Rehder & 37 \\
\hline & $\mathrm{P} 04$ & 1356 & Clay/Loam & Lithocarpus philippinensis (A.DC.) Rehder & 32 \\
\hline & $\mathrm{P} 05$ & 1382 & Clay/Loam & Syzygium sp.1 & 40 \\
\hline & P06 & 1350 & Clay/Loam & Syzygium sp.1 & 33 \\
\hline & $\mathrm{P} 07$ & 1416 & Clay/Loam & Lithocarpus philippinensis (A.DC.) Rehder & 50 \\
\hline & $\mathrm{P} 08$ & 1429 & Clay/Loam & Lithocarpus sp.3 & 28 \\
\hline & P09 & 1461 & Clay/Loam & Engelhardtia serrata Blume & 24 \\
\hline & P13 & 1267 & Clay/Loam & Lithocarpus philippinensis (A.DC.) Rehder & 33 \\
\hline & $\mathrm{P} 14$ & 1254 & Clay/Loam & Lithocarpus philippinensis (A.DC.) Rehder & 32 \\
\hline \multirow{11}{*}{ TUpperMontaneRF } & $\mathrm{P} 15$ & 1524 & Clay/Loam & Syzygium sp.1 & 28 \\
\hline & $\mathrm{P} 16$ & 1543 & Clay/Loam & Lithocarpus philippinensis (A.DC.) Rehder & 15 \\
\hline & $\mathrm{P} 17$ & 1570 & Clay/Loam & Lithocarpus philippinensis (A.DC.) Rehder & 53 \\
\hline & P18 & 1585 & Clay/Loam & Lithocarpus philippinensis (A.DC.) Rehder & 17 \\
\hline & P19 & 1605 & Clay/Loam & Lithocarpus philippinensis (A.DC.) Rehder & 25 \\
\hline & $\mathrm{P} 20$ & 1620 & Clay/Loam & Lithocarpus philippinensis (A.DC.) Rehder & 23 \\
\hline & $\mathrm{P} 21$ & 1599 & Clay/Loam & Lithocarpus philippinensis (A.DC.) Rehder & 22 \\
\hline & $\mathrm{P} 22$ & 1641 & Clay/Loam & Agathis philippinensis Warb. & 21 \\
\hline & $\mathrm{P} 10$ & 1512 & Clay/Loam & Syzygium sp. 1 & 20 \\
\hline & $\mathrm{P} 11$ & 1524 & Clay/Loam & Syzygium sp. 4 & 26 \\
\hline & $\mathrm{P} 12$ & 1553 & Clay/Loam & Syzygium sp. 1 & 33 \\
\hline \multirow{11}{*}{ Mossy Pygmy Forest } & $\mathrm{P} 30$ & 1870 & Clay/Loam & Dacrydium beccarii Parl. & 42 \\
\hline & $\mathrm{P} 31$ & 1866 & Clay/Loam & Dacrydium beccarii Parl. & 30 \\
\hline & $\mathrm{P} 32$ & 1856 & Clay/Loam & Dacrydium beccarii Parl. & 34 \\
\hline & P33 & 1858 & Clay/Loam & Dacrydium beccarii Parl. & 31 \\
\hline & $\mathrm{P} 23$ & 1836 & Clay/Loam & Dacrydium beccarii Parl. & 51 \\
\hline & $\mathrm{P} 24$ & 1854 & Clay/Loam & Leptospermum amboinense Blume & 46 \\
\hline & $\mathrm{P} 25$ & 1846 & Clay/Loam & Leptospermum amboinense Blume & 52 \\
\hline & $\mathrm{P} 26$ & 1855 & Clay/Loam & Leptospermum amboinense Blume & 60 \\
\hline & P27 & 1868 & Clay/Loam & Dacrydium beccarii Parl. & 66 \\
\hline & $\mathrm{P} 28$ & 1878 & Clay/Loam & Dacrydium beccarii Parl. & 65 \\
\hline & P29 & 1883 & Clay/Loam & Dacrydium beccarii Parl. & 53 \\
\hline \multirow{6}{*}{ FUltramafic } & P34 & 1562 & Loam/Gravel & Leptospermum amboinense Blume & 52 \\
\hline & $\mathrm{P} 35$ & 1574 & Loam/Gravel & Leptospermum amboinense Blume & 31 \\
\hline & P36 & 1590 & Loam/Gravel & Astronia $\mathrm{sp.}$ & 17 \\
\hline & P37 & 1608 & Loam/Gravel & Leptospermum amboinense Blume & 50 \\
\hline & P38 & 1617 & Loam/Gravel & Agathis philippinensis Warb. & 28 \\
\hline & P39 & 1605 & Loam/Gravel & Leptospermum amboinense Blume & 57 \\
\hline
\end{tabular}

Notes: TLowerMontaneRF-Tropical Lower Montane Rainforest; TUpperMontaneRF-Tropical Upper Montane Rainforest; FUltramafic-Forest over Ultramafic soil.

Freycinetia sp., Areca costulata, Pinanga philippinensis, Heterospathe philippinensis, Coelogyne salvaneraniana W. Suarez, Medinilla myrtiformis (Naudin) Triana, Sarcopyramis napalensis Wall, Sarcandra glabra (Thunb.) Nakai, Dendrochilum longilabre (Ames) Pfitzer, Lasianthus clementis Merr., Mackinlaya celebica, Rhododendron quadrasianum S. Vidal, Hornstedtia lophophora Ridl., and Agalmyla persimilis Hilliard \& Burtt.

\section{Mossy-pygmy forest}

The forest is characterized by higher elevation, 1800-1900 masl, lower canopy (1-15 m tall) (78\%), 10-19 cm DBH (74\%) and $0.8 \mathrm{~m}^{2} /$ ha average BA. Dominant species were Dacrydium beccarii (Podocarpaceae), 65.5 mean dominance, 123 IVI and Leptospermum amboinense (Myrtaceae), 53 mean dominance and 80 IVI. Other dominant tree taxa include Aconychia sp., Pandanus sp. and Phyllocladus hypophyllus Hook.f., tree with highest DBH, L. amboinense $(40 \mathrm{~cm})$. Emergent trees were Dacrydium beccarii and L. amboinense. The dominant ferns and lycophytes includes Abrodictyum pluma Ebihara \& K. Iwats., Blechnum vulcanicum, Dicranopteris linearis (Burm.f.) Underw., Dipteris conjugata Reinw., Gleichenia dicarpa R. Br., Hymenophyllum pallidum (Blume) Ebihara, Lycopodiella cernua, Oreogrammitis dolichosora Parris, Radiogrammitis 
setigera Parris, and Sphaeropteris robinsonii (Copel.) R.M. Tryon. The other understory plants included the site endemic pitcher plant, Nepenthes ceciliae Gronem., Coritico, Micheler, Marwinski, Acil \& V.B.Amoroso and N. pulchra, Aeschynanthus sp., Alpinia apoensis Elmer, A. musifolia Ridl., Areca costulata, Freycinetia sp., Medinilla myrtiformis, Heterospathe philippinensis and Heterospathe sp., Pinanga philippinensis, Vaccinium microphyllum Reinw. ex Blume and V. myrtoides (Blume) Miq.

\section{Forest over ultamafic rocks}

Situated at 1500-1700 masl is an ultramafic forest characterized by mixture of loam and gravel substrate, upper canopy (88\%), 10-19 $\mathrm{cm} \mathrm{DBH} \mathrm{(49 \% )} \mathrm{and} 1.8 \mathrm{~m}^{2} / \mathrm{ha}$ average BA. Dominant species were L. amboinense (Myrtaceae), 44 mean dominance, 94 IVI and Gymnostoma rumphianum (Jungh. Ex Vriese) L.A.S. Johnson 47 IVI. Other dominant tree taxa include Acronychia sp., Syzygium sp. 1 and A. philippinensis, tree with highest $\mathrm{DBH}, L$. amboinense $(65 \mathrm{~cm})$. Emergent trees were $L$. amboinense and A. philippinensis. The dominant ferns and lycophytes includes A. rufopannosa, A. pluma, Lindsaea hamiguitanensis D.N. Karger \& V.B. Amoroso, $P$. egenolfioides, Taenitis blechnoides (Willd.) Sw., T. pinnatum, and Hymenophyllum spp. The other understory plants include the site endemic pitcher plant, $N$. ceciliae, $N$. talaandig Gronem., Coritico, Wistuba, Micheler, Marwinski, Gieray \& V.B.Amoroso, Medinilla spp., and some species of orchids.

The lower parts of Mt. Tago range at $c a$. 500-1100 m as1 has been cleared due to the logging concession $c a$. 35-40 years ago and as direct result of land conversion for agriculture and human settlements. Some of these areas are now grassland and planted with different exotic species of plants such as Acacia mangium Willd. and Falcataria moluccana (Miq.) Barneby \& J.W. Grimes, different fruit trees and other agricultural crops. Generally, the lower parts of the high mountain ecosystems in the Philippines such as in Mt. Kitanglad, Bukidnon, Mt. Apo, North Cotabato and Davao del Sur, Mt. Canlaon, Negros Occidental, Mt. Pulag, Benguet were already converted to agricultural lands and the original vegetation which is the lowland forest dominated by dipterocarps has disappeared.

\section{Forest Structure}

Forest stand data across forest habitats (Table 3) suggests that majority of the tree population $(n=1,032)$ fall under diameter class $10-19 \mathrm{~cm} \mathrm{DBH} \mathrm{(53 \% )} \mathrm{and} \mathrm{height} \mathrm{class} 16-30 \mathrm{~m}$ (48\%). The relatively low percentage (11 and $12 \%)$ of the tree population with $30-39 \mathrm{~cm}$ and $\geq 40 \mathrm{~cm}$ DBH respectively is attributed to environmental conditions and anthropogenic activity. Majority (79\%) of the trees fall under upper canopy, (48\%) and emergent (31\%). Tree populations across forest habitats were observed to be emergent at lower elevations (1000 $-1500 \mathrm{~m}$ asl) becoming upper canopy at $1500-1800 \mathrm{~m}$ asl and lower canopy at 1800-1900 m asl. Similar pattern was observed in Mt. Kitanglad (Amoroso et al., 2011). The dominant DBH class in the site is comparable with Mount Lantoy (KBA), Cebu where majority of the tree populations have 10-19 cm (Lillo et al., 2019).

Mt. Tago Range is comparable to the other mountain ecosystems in Mindanao viz. Mt. Kitanglad, Mt. Malindang and Mt. Hamiguitan and Mt. Kiamo (Amoroso et al. 2011; Amoroso et al., 2012; Amoroso \& Aspiras, 2011; Coritico \& Amoroso, 2017) having similarities in species composition.

\section{Species Importance value index (IVI)}

Results showed that IVI values of tree taxa in the lower montane rainforest range from 1.4-47; upper montane rainforest, $0.8-42$; mossy-pygmy forest, $2.2-123$ and forest over ultramafic, 2.1-94. Highest IVI's in the mossy-pygmy forest and ultramafic forest over rocks are higher than the range of IVI's for tropical forest (12.5-52.4) (Pipoly \& Madulid, 1997) while the lower montane and upper montane forest fall within the range. Lithocarpus philippinensis with an IVI value of 47 and 42 respectively is the most dominant species in the lower and upper montane forest; Dacrydium beccarii (IVI = 123) in the mossy-pygmy forest and Leptospermum amboinense (IVI = 94 ) in the forest over ultramafic soil. Other dominant species in the site include Gymnostoma rumphianum (IVI = 47), Pandanus copelandii Merr. (IVI = 19), Syzygium sp. $1($ IVI = 34.4) and Shorea polysperma $(\mathrm{IVI}=11)($ Table 4$)$.

Tree inventories in Mt. Kitanglad (Amoroso et al., 2011), Mt. Kiamo (Coritico \& Amoroso, 2017) and Mt. Tago Range suggested common dominant genera i.e. Lithocarpus (Fagaceae) and Leptospermum which are attributed to same environmental conditions. The lower and upper montane forest habitat in Mt. Tago Range was comparable to the lower montane and lower mossy forest of Mt. Kitanglad (Amoroso et al., 2011), respectively, in terms of dominant species i.e. Lithocarpus and Syzygium (Myrtaceae). The mossy forests in both mountain ecosystems have a common dominant genus (Leptospermum). Tree species in Mt. Tago Range i.e. Dacrydium beccarii, Leptospermum amboinense and Lithocarpus sp. 3 have higher indices than the range of IVIs for tropical forest (Pipoly \& Madulid 1994). 
Table 3. Basal area and frequency of trees across diameter and height classes per forest habitat type.

\begin{tabular}{|c|c|c|c|c|c|c|c|c|}
\hline \multirow{3}{*}{ Forest habitat types } & \multirow{3}{*}{$\begin{array}{l}\text { Basal Area } \\
\text { (Average) }\end{array}$} & \multicolumn{7}{|c|}{ Frequency } \\
\hline & & \multicolumn{4}{|c|}{$\%$ Diameter classes $(\mathrm{cm})$} & \multicolumn{3}{|c|}{ \%Height classes (m) } \\
\hline & & $10-19$ & $20-29$ & $30-39$ & $\geq 40$ & $1-15$ & $16-30$ & $\geq 31$ \\
\hline TLowerMontaneRF & $1.5 \mathrm{~m}^{2} / \mathrm{ha}$ & 54 & 30 & 8 & 8 & 0 & 8 & 92 \\
\hline TUpperMontaneRF & $2.5 \mathrm{~m}^{2} / \mathrm{ha}$ & 37 & 30 & 15 & 18 & 2 & 58 & 40 \\
\hline Mossy-Pygmy Forest & $0.8 \mathrm{~m}^{2} / \mathrm{ha}$ & 74 & 19 & 5 & 2 & 78 & 22 & 0 \\
\hline FUltramafic & $1.8 \mathrm{~m}^{2} / \mathrm{ha}$ & 49 & 28 & 11 & 11 & 10 & 88 & 2 \\
\hline
\end{tabular}

Notes: TLowerMontaneRF-Tropical Lower Montane Rainforest; TUpperMontaneRF-Tropical Upper Montane Rainforest; FUltramafic-Forest over Ultramafic soil.

Table 4. Species with high Importance Value Index (IVI) in different forest habitat types.

\begin{tabular}{|c|c|c|}
\hline Forest habitat types & Species & IVI \\
\hline \multirow{3}{*}{ TLowerMontaneRF } & Lithocarpus philippinensis (A.DC.) Rehder & 47 \\
\hline & Syzygium sp. 1 & 24 \\
\hline & Shorea polysperma Merr. & 11 \\
\hline \multirow{3}{*}{ TUpperMontaneRF } & Lithocarpus philippinensis (A.DC.) Rehder & 42.4 \\
\hline & Syzygium sp. 1 & 34.4 \\
\hline & Acronychia sp. & 18.1 \\
\hline \multirow{3}{*}{ Mossy-Pygmy Forest } & Dacrydium beccarii Parl. & 123 \\
\hline & Leptospermum amboinense Blume & 80 \\
\hline & Pandanus copelandii Merr. & 19 \\
\hline \multirow{3}{*}{ FUltramafic } & Leptospermum amboinense Blume & 94 \\
\hline & Gymnostoma rumphianum (Jungh. ex Vriese) L.A.S.Johnson & 47 \\
\hline & Acronychia sp. & 31 \\
\hline
\end{tabular}

Notes: TLowerMontaneRF-Tropical Lower Montane Rainforest; TUpperMontaneRF-Tropical Upper Montane Rainforest; FUltramafic-Forest over Ultramafic soil.

\section{Notes on conservation status, endemicity and biodiversity threats}

Assessment of conservation and ecological status revealed that of the 121 tree species, $11(8 \%)$ are threatened, $28(22 \%)$ Least Concern (LC) and 16 (12\%) Philippine endemics (IUCN 2020; DENR (2017) (Table 5). Philippine endemics i.e. Shorea contorta Vidal and $S$. polysperma were categorized (DENR 2017) as VU but were listed as LC by the IUCN (2020). Further, Podocarpus rumphii Blume, which is categorized locally as VU, is listed as near threatened (NT) internationally. The reported number of threatened species herein, is relatively few compared to the reported threatened trees in Mt. Apo $(n=19)$ (Zapanta et al., 2019) and in the forest fragment in Cavite, Luzon ( $\mathrm{n}=39)$ (Causaren et al., 2017).

Endemicity assessment based on Pelser et al. (2011 onwards) revealed 16 endemics comprising $12 \%$ of the tree species in the study site. Endemic species in the study site were few compared to Mt. Lantoy, Cebu, with 76 endemic species
(Lilo et al., 2019) and in the forest fragments in Cavite, Luzon, with 44 endemics (Causaren et al., 2017).

The current study however revealed that Mt. Tago Range lacked proper legislative measure to curb the existing anthropogenic threats and pressures. This has resulted in continuous land conversion for agriculture and settlement, illegal logging and poaching.

\section{Conclusion and Recommendation}

Tree surveys in Mt. Tago Range documented a total of 1,032 trees belonging to 54 families, 85 genera and 121 species of trees. The site is composed of four tropical forest habitat types namely: lower montane rainforest, upper montane rainforest, mossy-pygmy and forest over ultramafic rocks. The highest diversity index was observed in the mid-elevation and decreasing toward the peak. The diversity pattern herein is attributed to elevation, forest degradation due to anthropogenic activities and 
Table 5. Threatened and endemic trees in Mt. Tago Range.

\begin{tabular}{|c|c|c|c|c|}
\hline \multirow[b]{2}{*}{ Family } & \multirow[b]{2}{*}{ Species } & \multicolumn{3}{|c|}{ Conservation Status } \\
\hline & & $\begin{array}{l}\text { IUCN } \\
(2020)\end{array}$ & $\begin{array}{l}\text { DENR } \\
\text { (2017) }\end{array}$ & $\begin{array}{l}\text { Endemicity } \\
\text { Pelser et al. } \\
\text { (2011 onwards) }\end{array}$ \\
\hline Aceraceae & Acer laurinum Hassk. & $\mathrm{LC}$ & - & - \\
\hline \multirow{2}{*}{ Actinidiaceae } & Saurauia avellana Elmer & - & - & $\mathrm{PE}$ \\
\hline & Saurauia clementis Merr. & - & - & $\mathrm{PE}$ \\
\hline \multirow{3}{*}{ Araliaceae } & Osmoxylon simplicifolium (Elmer) Philipson & - & - & $\mathrm{PE}$ \\
\hline & Aralia bipinnata Blanco & - & - & PE \\
\hline & Mackinlaya celebica (Harms) Philipson & $\mathrm{LC}$ & - & - \\
\hline Araucariaceae & Agathis philippinensis Warb. & & $\mathrm{VU}$ & $\mathrm{PE}$ \\
\hline \multirow{3}{*}{ Burseraceae } & Canarium asperum Benth. & LC & - & - \\
\hline & Canarium hirsutum Willd. & LC & - & - \\
\hline & Dacryodes rostrata (Blume) H.J.Lam & LC & OTS & - \\
\hline Casuarinaceae & Gymnostoma rumphianum (Jungh. ex Vriese) L.A.S.Johnson & - & OTS & - \\
\hline Chloranthaceae & Ascarina philippinensis C.B.Rob. & $\mathrm{LC}$ & - & - \\
\hline Clusiaceae & Garcinia vidalii Merr. & $\mathrm{LC}$ & - & $\mathrm{PE}$ \\
\hline \multirow{3}{*}{ Dipterocarpaceae } & Shorea assamica Dyer & $\mathrm{LC}$ & - & - \\
\hline & Shorea contorta S. Vidal & LC & VU & $\mathrm{PE}$ \\
\hline & Shorea polysperma (Blanco) Merr. & $\mathrm{LC}$ & VU & $\mathrm{PE}$ \\
\hline Euphorbiaceae & Macaranga bicolor Mull. Arg. & $\mathrm{VU}$ & OTS & $\mathrm{PE}$ \\
\hline Gnetaceae & Gnetum gnemon L. & LC & - & - \\
\hline Juglandaceae & Engelhardtia serrata Blume & $\mathrm{LC}$ & - & - \\
\hline \multirow{3}{*}{ Lauraceae } & Cinnатотит mercadoi Vidal & VU & OTS & PE \\
\hline & Cinnamoтит utile Kosterm. & - & - & $\mathrm{PE}$ \\
\hline & Litsea fulva (Blume) Fern.-Vill. & LC & - & - \\
\hline Melastomataceae & Astronia cumingiana S. Vidal & $\mathrm{LC}$ & - & $\mathrm{PE}$ \\
\hline \multirow{2}{*}{ Meliaceae } & Aglaia luzoniensis (S. Vidal) Merr. \& Rolfe & LC & - & - \\
\hline & Aglaia tomentosa Teijsm. \& Binn. & $\mathrm{LC}$ & - & - \\
\hline \multirow{6}{*}{ Moraceae } & Artocarpus treculianus Elmer & LC & - & $\mathrm{PE}$ \\
\hline & Ficus ampelas Burm. & LC & - & \\
\hline & Ficus fiskei Elmer & $\mathrm{LC}$ & - & $\mathrm{PE}$ \\
\hline & Ficus minahassae (Teijsm. \& Vriese) Miq. & $\mathrm{LC}$ & - & - \\
\hline & Ficus nota (Blanco) Merr. & LC & - & - \\
\hline & Ficus septica Burm. & $\mathrm{LC}$ & - & - \\
\hline Myristicaceae & Knema glomerata (Blanco) Merr. & LC & - & - \\
\hline Myrtaceae & Decaspermum vitis-idaea Stapf & $\mathrm{LC}$ & - & - \\
\hline Phyllanthaceae & Bischofia javanica Blume & $\mathrm{LC}$ & - & - \\
\hline Pittosporaceae & Pittosporum resiniferum Hemsl. & - & OTS & - \\
\hline 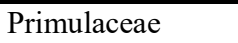 & Ardisia darlingii Merr. & - & - & $\mathrm{PE}$ \\
\hline \multirow{5}{*}{ Podocarpaceae } & Dacrycarpus cumingii (Parl.) de Laub. & $\mathrm{LC}$ & - & - \\
\hline & Dacrydium beccarii Parl. & $\mathrm{LC}$ & - & - \\
\hline & Falcatifolium gruezoi de Laub. & NT & - & - \\
\hline & Phyllocladus hypophyllus Hook. & LC & - & - \\
\hline & Podocarpus rumphii Blume & NT & VU & - \\
\hline Rubiaceae & Nauclea orientalis (L.) L. & $\mathrm{LC}$ & - & - \\
\hline Sapindaceae & Harpullia arborea (Blanco) Radlk. & LC & - & - \\
\hline Sapotaceae & Palaquium philippense (Perr.) C.B. Rob. & $\mathrm{VU}$ & VU & $\mathrm{PE}$ \\
\hline \multirow{2}{*}{ Theaceae } & Polyspora luzonica (S. Vidal) Orel, P.G. Wilson, Curry \& Luu & LC & - & - \\
\hline & Camellia lanceolata (Blume) Seem. & - & VU & - \\
\hline
\end{tabular}

Notes: VU-Vulnerable; OTS-Other Threatened Species; PE-Philippine Endemic 
nature of habitat. Assessment of conservation and ecological status revealed that 11 species $(8 \%)$ are threatened, $28(22 \%)$ Least Concern (LC) and $16(12 \%)$ are Philippine endemics. Threats to tree diversity in Mt. Tago Range include land conversion for agriculture and settlement, illegal logging and lack of legislative protection. The implementation of conservation strategies by stakeholders are recommended to protect the tree species communities and population across the forest habitat types in the site.

\section{Acknowledgement}

The authors are grateful to the Department of Environment and Natural Resources (DENR) Region $\mathrm{X}$ for the Gratuitous Permit, Central Mindanao University Administration, Bukidnon Higaonon Tribal Association (BUHITA) and the Local Government Unit of Kibalabag, Malaybalay City for the logistics support. Most importantly, sincere and utmost gratitude is conveyed to the Department of Science and Technology-Grants-InAid (DOST-GIA) for funding this research, and Philippine Council for Agriculture, Aquatic and Natural Resources Research and Development (PCAARRD) for monitoring this research project.

\section{Literature Cited}

Ambal, R.G.R., M.V. Duya, M.A. Cruz, O.G. Coroza, S.G. Vergara, N. De Silva, N. Molinyawe, \& B. Tabaranza, 2012. Key biodiversity areas in the Philippines: priorities for conservation. Journal of Threatened Taxa, 4: 2788-2796.

Amoroso, V.B., F.M. Acma, F.P. Coritico, F.S. Gorme, N.E. Lagunday, Mary Cor S. Salolog \& R.D. Colong, 2018. Floral diversity assessment of the buffer zones and vicinity of the Mt. Hamiguitan Range Wildlife Sanctuary (MHRWS) Davao Oriental: basis for inclusion to protected area zone. Philippine Journal of Systematic Biology, 12 (2): 36-51.

Amoroso, V.B., C.B. Amoroso \& F.P. Coritico, 2012. Diversity and status of plants in three mountain ecosystems in southern Mindanao, Philippines. Asian Journal of Biodiversity, 83: 50-73.

Amoroso, V.B. \& R.A. Aspiras, 2011. Hamiguitan Range: A sanctuary for native flora. Saudi Journal of Biological Sciences, 18: 7-15.

Amoroso, V.B., S.H. Laraga \& B.V. Calzada, 2011. Diversity and assessment of plants in Mt. Kitanglad Range, Natural Park, Bukidnon, Southern Philippines. Garden's Bulletin Singapore, 63(1\&2): 219-236.
Apan, A., L.A. Suarez, T. Maraseni \& J.A. Castillo, 2017. The rate, extent and spatial predictors of forest loss (20002012) in the terrestrial protected areas of the Philippines. Applied Geography, 81: 32-42.

Arances, J.B., V.B. Amoroso, R. Comilap, C. Comilap, J.B. Galvezo, W.S. Gruezo, C. Lumaray, B. Montimar, G. Opiso, G. Pacut, C. Ridsdale, L. Rufila, S. Sacal, S. Tan \& L. Visser, 2004. Development of Participatory Methodology for Inventory and Assessment of Floral Resources and their Characterization in the Montane Forests of Mt. Malindang. PDM Press Inc. Quezon City, Philippines 1: 15-94.

Ashton, P.S., 2003. Floristic zonation of tree communities on wet tropical mountains revisited. Perspectives in Plant Ecology, Evolution and Systematics, 6(1-2): 87-104.

Bankoff, G., 2007. One island too many: reappraising the extent of deforestation in the Philippines prior to 1946. Journal of Historical Geography, 33: 314-334.

Briones, N.D., 2007. Environmental sustainability issues in Philippine agriculture. Asian Journal of Agriculture and Development, 2: 67-78.

Causaren, R.M., R.D. Lagat \& E.M.G. Agoo, 2017. Tree species diversity of the remaining forest fragments in Cavite, Luzon Island, Philippines. Philippine Journal of Systematic Biology, 11(2): 56-73.

Coritico, F.P \& Amoroso V.B., 2017. A rapid assessment of vascular plants in Mt. Kiamo, Mindanao, Philippines. Asian Journal of Biodiversity, 8 (1):62-78.

Coritico, F.P \& A. Fleischmann, 2016. The first record of the boreal bog species Drosera rotundifolia (Droseraceae) from the Philippines, and a key to the Philippine sundews. Blumea, 61: 24-28.

Cruz, M.C. \& I. Zosa-Feranil, 1988. Policy implications of population pressure in the Philippines, Paper prepared for the World Bank study on forestry, fisheries and agricultural resource management, University of the Philippines, Los Baños, Philippines.

DENR Administrative Order, 2017. Updated national list of threatened philippine plants and their categories (DAO No. 2017-11).

Fernando, E.S., M.H. Suh \& D.K. Lee, 2008. Forest Formations of the Philippines. ASEAN-Korea Environmental Cooperation Unit (AKECU), Seoul.

Gregorio, N., U. Doydora, S. Harrison, J. Herbohn \& J. Sebua, 2009. Inventory and assessment of mother trees of indigenous timber species in Leyte Island and Southern Mindanao, Philippines. ACIAR Seedling Enhancement Project, 1: 113-125. 
Gronemeyer, T., F. Coritico, A. Wistuba, D. Marwinski, T. Gieray, M. Micheler, F.S. Mey \& V. Amoroso, 2014. Four new species of Nepenthes L. (Nepenthaceae) from the central mountains of Mindanao, Philippines. Plants, 3: 284-303.

IUCN 2020. The IUCN Red List of Threatened Species. Version 2020-1.

Lillo, E.P., A.B. Malaki, S.M.T. Alcazar, R.U. Nuevo \& R. Rosales, 2019. Native trees on Mount Lantoy Key Biodiversity Areas (KBA), Argao, Cebu, Philippines. Philippine Journal of Science, 148(2): 359-371.

Lulekal E., E. Kelbessa \& Y.H. Bekelet,2008. Plant species composition and structure of the Mana Angetu moist montane forest, southeastern Ethiopia. Journal of East African Natural History, 97: 165-185.

Madulid, D.A., 2000. Philippine Plants: Endangered Plants. Island Publishing House, Manila.

Magurran, A.E., 2004. Measuring Biological Diversity. Blackwell, Malden MA.

Malabrigo, P.L. Jr., A.B. Tobias \& J.C. Boncodin, 2018. Floristic composition, vegetation structure, and diversity pattern of Mt. Calavite Wildlife Sanctuary: Basis for management and conservation planning. Ecosystems \& Development Journal, 8(2): 3-27.

Moya, T.B. \& B.S. Malayang, 2004. Climate variability and deforestation- reforestation dynamics in the Philippines. Environment, Development and Sustainability, 6: 261277.

Myers, N., R.A. Mittermeier, C.G. Mittermeier, G.A.B. Fonseca \& J. Kent, 2000. Biodiversity hotspots for conservation priorities. Nature, 403: 853-858.

Nguyen, H., D. Lamb, J. Herbohn \& J. Firn, 2014. Designing mixed species tree plantations for the tropics: Balancing ecological attributes of speces with landholder preferences in the Philippines. PLoS ONE, 9(4): e95267.

Pelser, P.B., J.F. Barcelona \& D.L. Nickrent (eds.), 2011 onwards. Co's Digital Flora of the Philippines. www.philippineplants.org.

Pipoly, J., \& D. Madulid, 1994. The vegetation of a submontane moist forest on Mt. Kinasalapi, Kitanglad Range, Mindanao, Philippines. In: Dransfield, J., Coode, M. J. E. \& D.A. Simpson, (eds.), Plant Diversity in Malesia III. U. K. Royal Botanic Gardens, Kew.

Polinar, A.N. \& U. Muuss, 2010. Tree species diversity in secondary forest of Mount Pangasugan, Baybay City, Philippines. Journal of Nature Studies, 9(1): 105-111.

Posa, M.R.C. \& N.S. Sodhi, 2006. Effects of anthropogenic land use on forest birds and butterflies in Subic Bay, Philippines. Biological Conservation, 129: 256-270.
Shannon, C.E. \& W. Wiener, 1949. The Mathematical Theory of Communication. Urbana, IL: University of Illinois Press.

Sibucao, Jr. A., L.F. Aggabao, D.R. Gopez, J.A. Obejas, R. Velloza, 2014. Analysis of land coversepichange: 20032010. Unpublished Report. Forest Management Bureau, Department of Environment and Natural Resources, Quezon City, Philippines.

Simpson, E. H., 1949. Measurement of diversity. Nature 16: 688.

Suarez, R.K. \& P.E. Sajise, 2010. Deforestation, swidden agriculture and Philippine biodiversity. Philippine Science Letters, 3(1): 91-99.

Whitford, H., 1911. The Forests of the Philippines. Part I: Forest Types and Products. Department of the Interior Bureau of Forestry.

Zapanta B.R., M.J.M.M Achondo, A.F.M. Raganas, F.A. Camino, A.G.D. Delima, J.A. Mantiquilla, R.P. Puentespina, Jr. \& F.R.P. Salvana, 2019. Species richness of trees in disturbed habitats within a protected area and its implications for conservation: The case of Mt. Apo Natural Park, Mindanao Island, Philippines. Biodiversitas, 20(7): 2081-2091. 